\title{
A cost-effectiveness analysis of different therapies in patients with chronic hepatitis B in Italy
}

This article was published in the following Dove Press journal:

ClinicoEconomics and Outcomes Research

I5 February 201I

Number of times this article has been viewed

\section{Giorgio L Colombo',2 \\ Giovanni B Gaeta ${ }^{3}$ \\ Mauro Viganò ${ }^{4}$ \\ Sergio Di Matteo ${ }^{2}$}

'University of Pavia, School of Pharmacy, Italy; ${ }^{2}$ S.A.V.E. Studi Analisi

Valutazioni Economiche, Milan, Italy; ${ }^{3}$ Viral Hepatitis Unit, Second University, Naples, Italy; ${ }^{4}$ Liver Unit, Ospedale San Giuseppe, Università degli Studi di Milano, Milan, Italy
Correspondence: Giorgio L Colombo S.A.V.E. Studi Analisi Valutazioni Economiche,Via Previati,

$74-20149$ Milan, Italy

$\mathrm{Tel}+3902485$ I 923 I

$\mathrm{Fax}+390248198430$

Email giorgio.colombo@unipv.it
Introduction: Chronic hepatitis B (CHB) is a prevalent disease associated with high morbidity, mortality, and impact on health care costs. Antiviral therapy is aimed at reducing hepatitis B virus replication in order to limit progressive liver disease and improve the natural history of the disease. This study estimates the cost-effectiveness of lamivudine, adefovir, telbivudine, entecavir, tenofovir, and pegylated interferon in patients with CHB.

Methods: A Markov model was developed to evaluate the costs and benefits of antivirals in a cohort of patients with $\mathrm{CHB}$ (hepatitis B e antigen [HBeAg]-positive and HBeAg-negative) and cirrhosis over a period of 10 years. Different rescue therapies were considered, according to current guidelines. Data on efficacy and changes in quality of life were derived from clinical trials and epidemiological Italian data. Direct costs were assessed from the perspective of the Italian National Health Service.

Results: Tenofovir was associated with lower costs and higher efficacy compared with entecavir, telbivudine, and adefovir, as shown by their incremental cost-effectiveness ratios (ICER) per quality-adjusted life-year (QALY) gained: tenofovir €30,959, entecavir $€ 45,971$, telbivudine $€ 62,051$, and adefovir $€ 82,824$. Even following 1 year of pegylated interferon therapy, tenofovir had a more favourable ICER per QALY gained compared with the other rescue options. The analysis of patients with cirrhosis confirms the results obtained with the CHB cohort though with higher ICERs. Sensitivity analyses on the main variables confirm the results of the base case scenario.

Conclusion: Within the Italian health care system, in patients with $\mathrm{CHB}$, tenofovir is a cost-effective strategy compared with other available therapies. Public health care authorities would benefit from mathematical models designed to estimate the future burden of CHB infection together with the impact of treatment and drug resistance.

Keywords: chronic hepatitis B, Markov model, cost-effectiveness, lamivudine, adefovir, telbivudine, entecavir, tenofovir, pegylated interferon

\section{Introduction}

Chronic infection with hepatitis B virus (HBV) is a common cause of death associated with liver failure, cirrhosis, and hepatocellular carcinoma (HCC). ${ }^{1}$ Despite the implementation of vaccination programs in various countries, the condition is still widespread, affecting 350 million to 400 million people worldwide. ${ }^{2}$

Morbidity and mortality in chronic hepatitis $\mathrm{B}(\mathrm{CHB})$ are related to persistence of viral replication and evolution to cirrhosis or HCC. ${ }^{1}$ Treatment for $\mathrm{CHB}$ is therefore aimed at suppressing HBV replication to prevent progression of the disease. The current therapeutic options available in Italy and Europe include interferon $\alpha$, conventional 
or pegylated, and nucleoside/nucleotide analogs (NUCs). Interferon is administered subcutaneously, and its main advantage is the absence of resistance. Nonetheless, its use is limited by frequent side effects and the fact that it is considered a moderate antiviral agent. ${ }^{1}$ NUCs vary greatly in terms of efficacy, induced viral resistance, and tolerance. Lamivudine and adefovir are early-generation oral agents whose main disadvantage is the high viral resistance they engender. ${ }^{3}$ Telbivudine is a potent inhibitor of HBV but with a high rate of viral resistance. ${ }^{2}$ Conversely, the latestgeneration NUCs entecavir and tenofovir are both potent HBV inhibitors with an optimal resistance profile..$^{4-6}$

The relevant role of entecavir and tenofovir has recently been highlighted by the European Association for the Study of the Liver (EASL), whose guidelines recommend pegylated interferon, entecavir, or tenofovir as first-line treatment for both hepatitis B e antigen (HBeAg)-positive and $\mathrm{HBeAg}$-negative patients. ${ }^{1}$

Considering the complexity of the disease, the EASL's recommendations are invaluable in assisting physicians in selecting the most favourable therapies. However, because $\mathrm{CHB}$ is a prolonged illness, the treatment of which may continue for many years, the need for drugs with potent antiviral activity, proven long-term safety, and a low rate of HBV antiviral resistance ${ }^{1}$ should also be evaluated in terms of lifetime costs.

In a global context of limited health care resources, pharmacoeconomic considerations are a central factor to help policy makers make the most appropriate decisions on resource allocation. We therefore performed an economic analysis to estimate the cost-effectiveness of the treatments licensed in Italy for managing HBV infection in patients with chronic hepatitis and cirrhosis. We also estimated the impact of the disease on the quality of life of patients.

\section{Patients and method Model overview}

We built a Markov model and evaluated the clinical and economic outcomes of a hypothetical cohort of 100 subjects (aged $\geq 18$ years) with chronic HBV $(92.70 \%)$ or cirrhosis $(7.30 \%)$ over a 10 -year horizon. The proportions of the two subpopulations were obtained from a study by Giannini et al. ${ }^{7}$

To mirror the case mix in clinical practice in Italy, we assumed that $20 \%$ of them were $\mathrm{HBeAg}$-positive and $80 \%$ were $\mathrm{HBe} A g$-negative. ${ }^{8}$ The terms "HBeAg-positive" and "HBeAg-negative" define two categories of the CHB status, the first typically represents the early phase of chronic HBV infection, whereas the second represents a later phase. ${ }^{1}$

In the model, the individual's possible prognosis is divided into distinct health states. Costs and benefits are assigned to each health state and the movement of an individual between these health states over a given amount of time (each cycle of 1 year) is defined by transition probabilities. The costs and benefits of comparative treatments are then estimated according to the time spent in each state.

Because $\mathrm{HBe} A g$-negative and $\mathrm{HBeAg}$-positive populations present a different clinical course, prognosis, and response to therapy, separate transition probabilities were assigned to each group.

The model, which is represented in Figure 1, was structured with the following assumptions:

- On entering the model, previously untreated subjects start to receive one of the following competing options: i) no treatment, ii) tenofovir monotherapy, iii) lamivudine monotherapy, iv) adefovir monotherapy, v) entecavir monotherapy, vi) telbivudine monotherapy, and vii) pegylated interferon monotherapy.

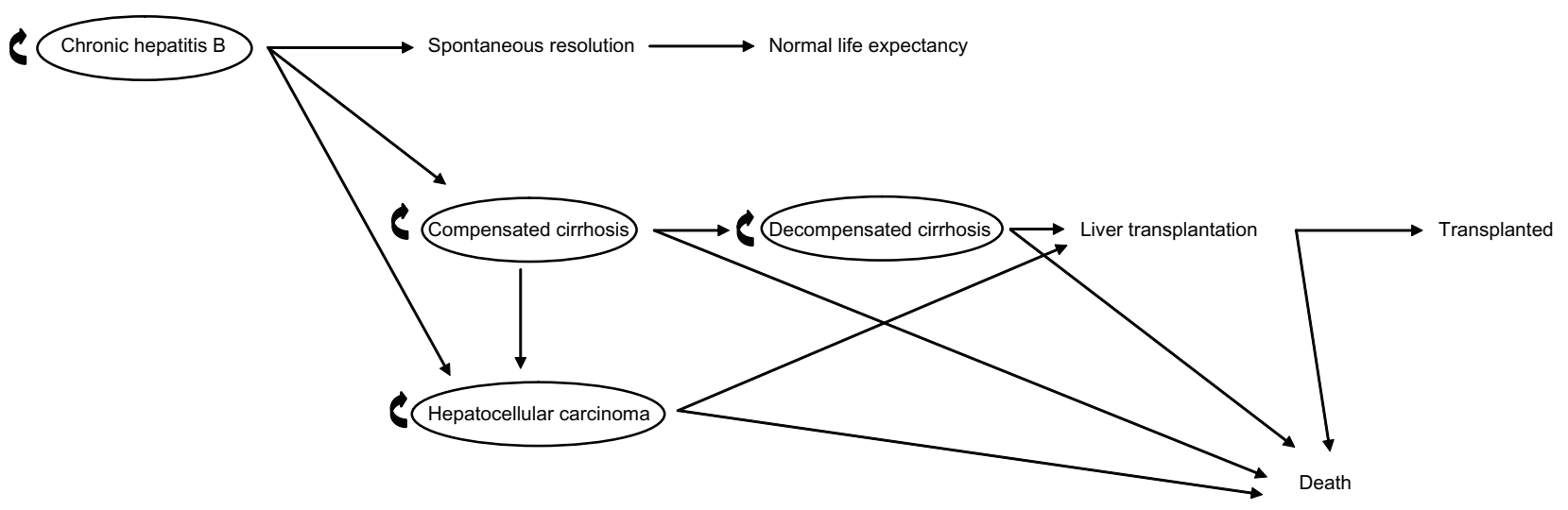

Figure I Structure of the Markov model for chronic hepatitis B. 
- At the end of each cycle (1 year), the subjects with virologic response remain in the same state, whereas nonresponders move to the subsequent health states.

- Subjects who do not respond or who develop resistance to treatment receive a rescue therapy, ie, a second drug, according to the following scheme:

$\begin{array}{lll}\text { Initial treatment } & & \begin{array}{l}\text { Rescue therapy } \\ \text { tenofovir }\end{array} \\ \text { lamivudine } & \rightarrow & \text { add-on entecavir } \\ \text { adefovir } & \rightarrow & \text { add-on tenofovir } \\ \text { entecavir } & \rightarrow & \text { add-on entecavir } \\ \text { telbivudine } & \rightarrow & \text { add-on tenofovir } \\ \text { pegylated interferon } & \rightarrow & \text { switch to entecavir or }\end{array}$

- In case of resistance, subjects with $\mathrm{CHB}$ remain in the state "chronic hepatitis B", whereas subjects with cirrhosis move to the subsequent states.

- Subjects who achieve HBeAg seroconversion discontinue therapy 12 months later; patients who achieve hepatitis B surface antigen (HBsAg) seroconversion discontinue therapy definitely.

According to the EASL guidelines, virologic response is achieved when HBV DNA level is reduced below the lower limit of detection of real-time polymerase chain reaction assays $(10-15 \mathrm{IU} / \mathrm{mL})$, resulting in biochemical remission, histological improvement, and prevention of complications. ${ }^{1}$

Seroconversion from $\mathrm{HBeAg}$ to anti-HBe antibodies with normal transaminases, leading to the "inactive HBV carrier state", represents the immunological control of the infection and reflects a favorable long-term outcome with a very low risk of cirrhosis or HCC in most subjects. ${ }^{1} \mathrm{HBsAg}$ loss or seroconversion is more rarely achieved and represents serologic recovery. ${ }^{2}$ Both these possibilities were considered in the model.

A discount rate was applied to costs and utilities (range 0\%-3\%). Modeling was undertaken using Microsoft Excel 2003 (Microsoft Corporation, Redmond, Washington, USA).

\section{Transition probabilities}

Subjects who received no treatment followed the natural history of $\mathrm{CHB}$ according to their HBeAg status. The corresponding transition probabilities were derived from a study by Idris et al. ${ }^{9}$ Subjects who received one of the six available therapeutic options progressed to virologic response, nonresponse, and resistance according to the drug they were given. The transition probabilities were derived from literature data (Tables 1 and 2). When data were not available, it was assumed that the response remained constant at the last observed value by applying the last value carried forward technique.

\section{Outcomes}

To evaluate cost-effectiveness, the incremental costeffectiveness ratio (ICER) was used. When the value of a new therapeutic option needs to be assessed, the ICER provides the additional resources that have to be used to achieve the additional benefit. ICER is the difference in cost $(\Delta C)$ divided by the difference in effect $(\Delta E)$ between two alternatives. In this analysis, the direct costs

Table I Input data of the base case scenario

\begin{tabular}{|c|c|c|c|c|}
\hline Variable & & Value & & Reference \\
\hline HBeAg-positive & & $20.00 \%$ & & 8 \\
\hline Chronic infection & & $92.70 \%$ & & 7 \\
\hline Cirrhosis & & $7.30 \%$ & & \\
\hline \multirow[t]{2}{*}{ Transition probabilities } & Annual rates of events & HBeAg & & \\
\hline & & Positive & Negative & \\
\hline \multirow[t]{3}{*}{ Chronic hepatitis B } & Spontaneous resolution & $6.90 \%$ & $1.60 \%$ & 9 \\
\hline & Compensated cirrhosis & $3.00 \%$ & $4.60 \%$ & \\
\hline & Hepatocellular carcinoma & $1.50 \%$ & $1.50 \%$ & \\
\hline \multirow[t]{3}{*}{ Compensated cirrhosis } & Decompensated cirrhosis & $7.30 \%$ & $7.30 \%$ & 9 \\
\hline & Hepatocellular carcinoma & $3.40 \%$ & $3.40 \%$ & \\
\hline & Death & $4.90 \%$ & $4.90 \%$ & \\
\hline \multirow[t]{2}{*}{ Decompensated cirrhosis } & Liver transplantation & $21.00 \%$ & $21.00 \%$ & 9 \\
\hline & Death & $19.00 \%$ & $19.00 \%$ & \\
\hline \multirow[t]{2}{*}{ Hepatocellular carcinoma } & Liver transplantation & $25.00 \%$ & $25.00 \%$ & 9 \\
\hline & Death & $43.30 \%$ & $43.30 \%$ & \\
\hline Liver transplantation & Death & $6.90 \%$ & $6.90 \%$ & 9 \\
\hline
\end{tabular}

Abbreviation: $\mathrm{HBeAg}$, hepatitis $\mathrm{B}$ e antigen. 
Table 2 Virologic response, HBV resistance, and seroconversion rates for each antiviral drug for both HBeAg-positive and -negative patients

\begin{tabular}{|c|c|c|c|c|c|c|}
\hline \multirow[t]{3}{*}{ List of variable } & \multicolumn{5}{|l|}{ Value } & \multirow[t]{3}{*}{ Reference } \\
\hline & \multicolumn{5}{|l|}{ Years } & \\
\hline & $\mathbf{I}$ & 2 & 3 & 4 & 5 & \\
\hline \multicolumn{7}{|c|}{ Undetectable HBV DNA } \\
\hline \multicolumn{7}{|l|}{ HBeAg-positive } \\
\hline Tenofovir & $76.00 \%$ & $78.00 \%$ & $72.00 \%$ & & & $5,10,11$ \\
\hline Lamivudine & $36.00 \%$ & & & & & 12,13 \\
\hline Adefovir & $21.00 \%$ & $40.00 \%$ & $48.00 \%$ & & & 13,14 \\
\hline Entecavir ${ }^{\prime}$ & $67.00 \%$ & $80.00 \%$ & $82.00 \%$ & & & 12,13 \\
\hline Telbivudine & $60.00 \%$ & $56.00 \%$ & & & & 15,16 \\
\hline Peginterferon & $25.00 \%$ & & & & & 1,13 \\
\hline \multicolumn{7}{|l|}{ HBeAg-negative } \\
\hline Tenofovir & $93.00 \%$ & $91.00 \%$ & $88.00 \%$ & & & $5,17,18$ \\
\hline Lamivudine & $89.00 \%$ & $63.00 \%$ & $48.00 \%$ & $39.00 \%$ & & 19 \\
\hline Adefovir & $72.00 \%$ & $80.00 \%$ & $77.00 \%$ & $73.00 \%$ & $67.00 \%$ & 20 \\
\hline Entecavir ${ }^{\mathrm{a}}$ & $90.00 \%$ & $94.00 \%$ & $93.00 \%$ & $91.00 \%$ & $95.00 \%$ & $|3,2|-24$ \\
\hline Telbivudine & $88.00 \%$ & $82.00 \%$ & & $84.00 \%$ & & 16,25 \\
\hline Peginterferon & $63.00 \%$ & & & & & 1,13 \\
\hline \multicolumn{7}{|c|}{ Development of resistance } \\
\hline \multicolumn{7}{|l|}{ HBeAg-positive } \\
\hline Tenofovir & $0.00 \%$ & $0.00 \%$ & $0.00 \%$ & & & $\mathrm{I}, \mathrm{II}, 26$ \\
\hline Lamivudine & $23.00 \%$ & $46.00 \%$ & $55.00 \%$ & $71.00 \%$ & $65.00 \%$ & 27 \\
\hline Adefovir & & & $20.00 \%$ & & & 28 \\
\hline Entecavir & $0.20 \%$ & $0.50 \%$ & $1.20 \%$ & $1.20 \%$ & $1.20 \%$ & 29 \\
\hline Telbivudine & $5.00 \%$ & $25.10 \%$ & & & & 15,30 \\
\hline Peginterferon & na & & & & & \\
\hline \multicolumn{7}{|l|}{ HBeAg-negative } \\
\hline Tenofovir & $0.00 \%$ & $0.00 \%$ & $0.00 \%$ & & & $1,18,26$ \\
\hline Lamivudine & $20.00 \%$ & $44.00 \%$ & & & $60.00 \%$ & $|9,3|$ \\
\hline Adefovir & $0.00 \%$ & $3.00 \%$ & $11.00 \%$ & $18.00 \%$ & $29.00 \%$ & 20 \\
\hline \multicolumn{7}{|l|}{ Entecavir } \\
\hline Telbivudine & $2.20 \%$ & $11.00 \%$ & & & & 15,30 \\
\hline Peginterferon & na & & & & & \\
\hline \multicolumn{7}{|c|}{ HBsAg clearance/seroconversion } \\
\hline \multicolumn{7}{|l|}{ HBeAg-positive } \\
\hline Tenofovir & $3.00 \%$ & $6.00 \%$ & $8.00 \%$ & & & $5,10,11$ \\
\hline Lamivudine & $0.00 \%$ & & & & & \\
\hline Adefovir & $0.00 \%$ & & & & & \\
\hline Entecavir & $2.00 \%$ & & & & & 4 \\
\hline Telbivudine & $0.00 \%$ & & & & & \\
\hline Peginterferon & $4.00 \%$ & $6.00 \%$ & $8.00 \%$ & & & 32,33 \\
\hline \multicolumn{7}{|l|}{ HBeAg-negative } \\
\hline Tenofovir & $0.00 \%$ & $0.00 \%$ & $0.00 \%$ & & & $5,17,18$ \\
\hline Lamivudine & $0.00 \%$ & $0.00 \%$ & $0.00 \%$ & & & \\
\hline Adefovir & $0.00 \%$ & $0.00 \%$ & $0.00 \%$ & & & \\
\hline Entecavir & $0.00 \%$ & & & & & \\
\hline Telbivudine & $0.00 \%$ & & & & & \\
\hline Peginterferon & $3.00 \%$ & $6.00 \%$ & $8.00 \%$ & & & 34,35 \\
\hline \multicolumn{7}{|c|}{ HBeAg seroconversion } \\
\hline \multicolumn{7}{|c|}{ HBeAg-positive } \\
\hline Tenofovir & $21.00 \%$ & $26.00 \%$ & $26.00 \%$ & & & $1,5,10,11,36$ \\
\hline Lamivudine & $22.00 \%$ & $22.50 \%$ & & & & $1,15,36$ \\
\hline Adefovir & $12.00 \%$ & $29.00 \%$ & $43.00 \%$ & & & $1,36-38$ \\
\hline Entecavir & $21.00 \%$ & $24.00 \%$ & & $16.00 \%$ & & I,36,38-40 \\
\hline Telbivudine & $23.00 \%$ & $30.00 \%$ & & & & $|, 36,4|$ \\
\hline Peginterferon & $30.00 \%$ & $41.00 \%$ & & & & $1,36,42$ \\
\hline
\end{tabular}

Note: ${ }^{a}$ Data beyond I year need to be interpreted with caution due to regimen intensification, including doubling of dose. 
Table 3 Cost data: average cost of different stages of the disease (€, year 2009 values) and annual drug costs

\begin{tabular}{lll}
\hline Antiviral & Annual cost $(\boldsymbol{\epsilon})$ & Reference \\
\hline Tenofovir & 3062.35 & 48 \\
Lamivudine & 1153.40 & 48 \\
Adefovir & 4595.35 & 48 \\
Entecavir & 4595.35 & 48 \\
Telbivudine & 4595.35 & 48 \\
Peginterferon & 8356.55 & 48 \\
Disease state & Annual cost $(\boldsymbol{\epsilon})^{\mathrm{a}}$ & \\
Chronic hepatitis B & 1977.02 & 49 \\
Compensated cirrhosis & 3384.56 & 49 \\
Decompensated cirrhosis & 3384.56 & 49 \\
Hepatocellular carcinoma & 6808.71 & 49 \\
Liver transplantation & 82867.40 & 49 \\
Follow-up post-transplantation & 6358.04 & 50 \\
Monitoring for nephrotoxic effects & 23.50 & 51 \\
& & 52 \\
\hline Not & &
\end{tabular}

Note: ${ }^{2}$ Costs of drugs are excluded.

and effectiveness of each drug were compared with the direct costs and effectiveness of the disease natural history (absence of treatment).

$$
\operatorname{ICER}=\frac{\left(\text { Cost }_{\text {drug }}-\text { Cost }_{\text {absence of treatment }}\right)}{\left(\text { Effectiveness }_{\text {drug }}-\text { Effectiveness }_{\text {absence of treatment }}\right)}
$$

\section{Utilities}

The analysis conducted is a cost-utility analysis, ie, an economic evaluation that estimates the cost per qualityadjusted life-year (QALY) gained from undertaking one intervention instead of another. ${ }^{43}$ The QALY is a potential measure of health and is obtained by multiplying the duration of a health state (in years) by a factor representing the quality ("utility") of that health state. A QALY value of 1 is equivalent to a year of "perfect health", whereas a value of zero corresponds to "death". Utilities were considered for the following states: virologic response (1.000), inactive HBV carrier (0.960), CHB (0.910), compensated cirrhosis (0.800), decompensated cirrhosis (0.600), HCC (0.730), and liver transplantation $(0.860){ }^{44-46}$ These values were calculated using the Health Utility Index (HUI). ${ }^{47}$

\section{Costs}

Only direct health care costs (ie, health service costs) were considered in the analysis, which were calculated from the Italian National Health Service's perspective. These costs pertained to annual costs per person and included expenditures related to the diagnosis of the disease, laboratory testing, drugs, follow-up, and disease complication costs. In the case of tenofovir, costs also included periodic monitoring of renal functioning, which was performed monthly during the first year and every 3 months for the following years (Table 3).

\section{Results}

The model was built using epidemiological data of CHB prevalence in Italy. Our results show that the mean annual cost per patient with CHB or cirrhosis receiving antiviral therapy was between $€ 2573$ and $€ 7639$ compared with subjects who received no treatment. The ICER per QALY gained for a) tenofovir monotherapy, b) pegylated interferon (first year) followed by tenofovir, c) pegylated interferon (first year) followed by entecavir, d) lamivudine with early add-on tenofovir, and e) entecavir monotherapy were all favorable at a threshold of $€ 50,000$ per QALY compared with the natural history of the disease and varied between $€ 30,959$ and $€ 45,971$ (Table 4). Conversely, telbivudine and adefovir did not have a favourable ICER compared with the natural history of the disease, as their range was between $€ 62,051$ and $€ 82,824$ per QALY gained (Table 4). Of note, because of the optimal combination of cost and effectiveness, tenofovir was the strategy with the best ICER.

Table 4 Results: costs, quality-adjusted life-years (QALYs), and incremental cost-effectiveness ratio (ICER) of the base case scenario (10-year horizon)

\begin{tabular}{|c|c|c|c|c|c|c|}
\hline \multirow[t]{2}{*}{ Treatment } & $\begin{array}{l}\text { Mean annual } \\
\text { cost per } \\
\text { patient (€) }\end{array}$ & $\begin{array}{l}\text { Mean annual } \\
\text { QALY per } \\
\text { patient }\end{array}$ & $\begin{array}{l}\text { Mean cost per } \\
\text { QALY (€) }\end{array}$ & Delta cost $(€)$ & $\begin{array}{l}\text { Delta } \\
\text { QALY }\end{array}$ & $\begin{array}{l}\text { ICER per } \\
\text { QALY (€) } \\
\text { I } 2 \text { months }\end{array}$ \\
\hline & $\mathbf{a}$ & $\mathbf{b}$ & $\mathbf{a} / \mathbf{b}$ & $\Delta \mathbf{a}$ & $\Delta \mathbf{b}$ & $\Delta \mathbf{a} / \Delta \mathbf{b}$ \\
\hline Natural history of disease & 2572.84 & 0.815 & 3158.74 & & & \\
\hline Tenofovir & 5116.00 & 0.896 & 5711.00 & 2543.00 & 0.081 & 31,291 \\
\hline Peginterferon (first year) $\rightarrow$ tenofovir & 5276.00 & 0.897 & 5883.00 & 2703.00 & 0.082 & 32,863 \\
\hline Peginterferon (first year) $\rightarrow$ entecavir & 6206.00 & 0.897 & 6922.00 & 3633.00 & 0.082 & 44,243 \\
\hline Lamivudine ( $\rightarrow$ add-on tenofovir) & 4737.00 & 0.862 & 5495.00 & 2164.00 & 0.048 & 45,513 \\
\hline Entecavir & 6302.00 & 0.895 & 7043.00 & 3729.00 & 0.080 & 46,498 \\
\hline Telbivudine & 6970.00 & 0.885 & 7878.00 & 4397.00 & 0.070 & 62,642 \\
\hline Adefovir & 7679.00 & 0.876 & 8769.00 & 5106.00 & 0.061 & 83,475 \\
\hline
\end{tabular}




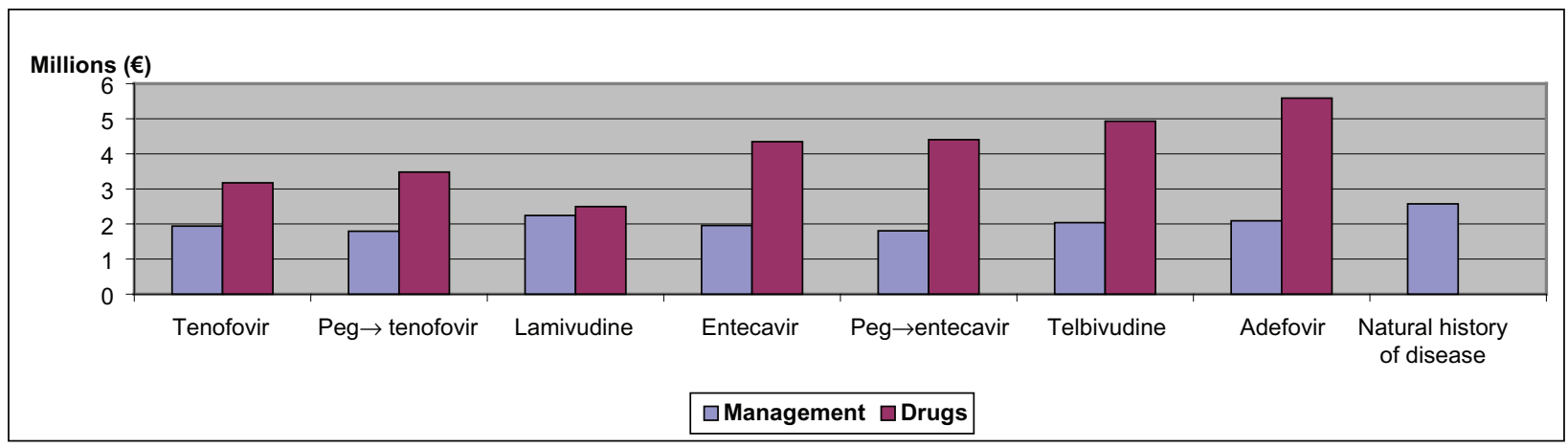

Figure 2 Total costs at 10 years for drugs and other health costs calculated for a cohort of 100 patients.

By estimating the cost of the different strategies at 5 and 10 years, we showed that tenofovir alone or following pegylated interferon in a group of $\mathrm{HBeAg}$-positive patients contributed to reducing the costs of disease management over time.

In our simulation, $\mathrm{HBe} A g$-positive subjects showed more favorable ICERs compared with HBeAg-negative subjects, whereas, as assessed in the sensitivity analyses, treatment of subjects with cirrhosis resulted in higher ICERs, which often exceeded the international threshold of cost-effectiveness of €25,000-35,000 (about £20,000-30,000) indicated, for example, by the National Institute for Health and Clinical Excellence (NICE) ${ }^{53}$

To test the robustness of our evaluations, sensitivity analyses were carried out by varying parameters such as the proportion of $\mathrm{HBeAg}$-positive and $\mathrm{HBeAg}$-negative subjects, the proportion of subjects with cirrhosis, the cost of tenofovir and entecavir, and the overall cost of patient management. Other sensitivity analyses were carried out for the inclusion of bone mineral densitometry for subjects on tenofovir and discounting for costs and QALYs. In all cases, the results of the base case scenario were confirmed (Table 5 and Figure 4).

\section{Discussion}

Chronic HBV infection is a prevalent disease, the management of which is associated with high costs due to treating complications, antiviral drug therapy, and monitoring of HBV drug resistance. ${ }^{9}$ Current guidelines have provided physicians with clear recommendations on how to select the most effective treatments for each patient. ${ }^{1}$ However, their indications have failed to include pharmacoeconomics considerations to address the financial burden of CHB and its consequences on the limited health care budgets of many countries.

To contribute to a better understanding of the impact of managing subjects with CHB in Italy, we have developed a cost-effectiveness analysis on the six treatments that are currently available. Our results have shown that tenofovir is the most cost-effective oral antiviral compared with the other agents for $\mathrm{HBeAg}$-positive and $\mathrm{HBeAg-negative} \mathrm{subjects}$ and for patients with cirrhosis. In the case of drug failure, the use of tenofovir and entecavir as rescue therapies has a more favorable ICER than the use of adefovir and lamivudine. Furthermore, tenofovir assessment has included costs for renal monitoring and bone mineral densitometry, which were not considered in the most recent published studies. ${ }^{6,54,55}$

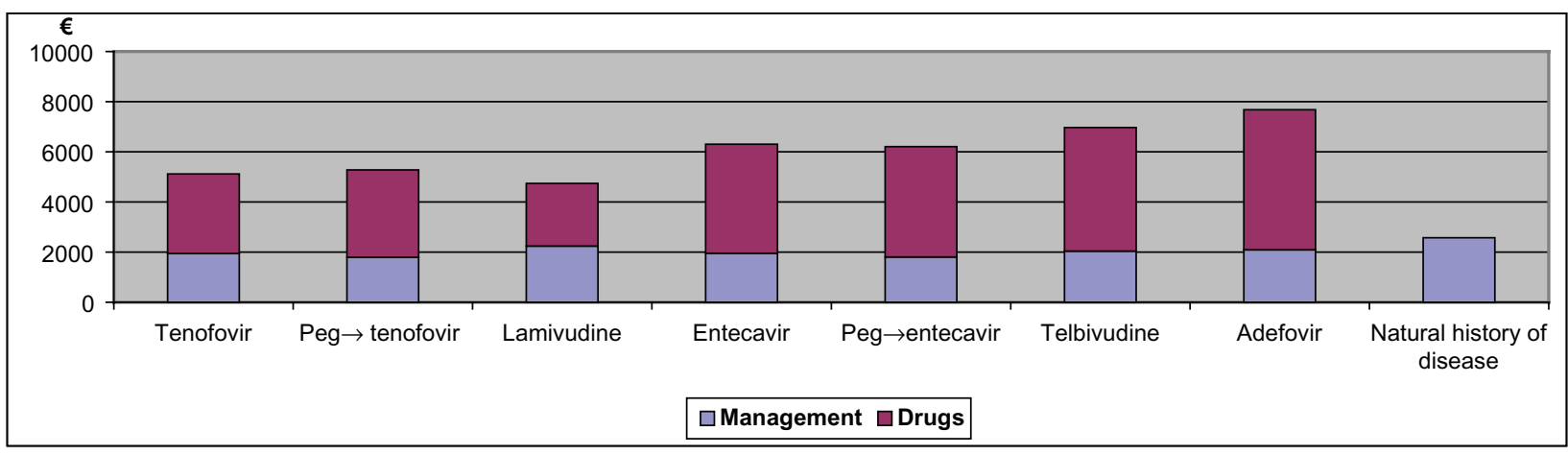

Figure 3 Mean cost per patient per year. 


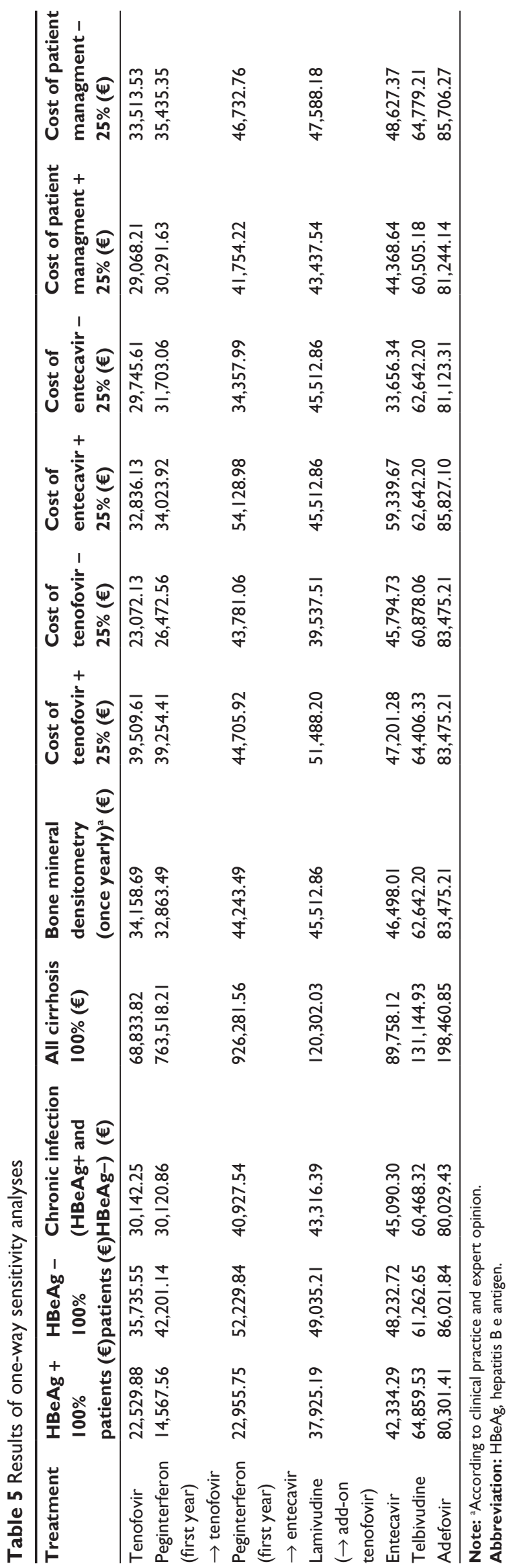

The ICER per QALY gained was below the threshold of $€ 23,000-34,000$ (about $£ 20,000-30,000$ ) set by NICE only in the case of tenofovir as first-line treatment or as rescue therapy following pegylated interferon. In all other cases, ICER per QALY gained exceeded NICE's threshold. Though no officially established threshold is available for Italy, it is worth noting that recent guidelines by the Italian Health Economics Association (AIES) ${ }^{56}$ recommend that a threshold of $€ 25,000-40,000$ be adopted. Other acceptable references of cost-effectiveness for the Italian context are $€ 36,500$ and $€ 60,000$ and have been calculated by two different authors. ${ }^{57,58}$

Our results are in line with other recent pharmacoeconomics analyses, in particular with the study of Buti et $\mathrm{al}^{54}$ and with the more recent cost-utility analysis of Dakin et al..$^{55}$ Unlike these two studies, though, which assessed only the cost-effectiveness of NUCs, we were also able to model the treatment with pegylated interferon and show that the strategy of using pegylated interferon (first year) followed by tenofovir may represent a good cost-effectiveness solution for $\mathrm{HBeAg}$ positive subjects, although this approach is not as cost-effective as starting with tenofovir for HBeAg-negative subjects. Conversely, peginterferon usage as first-line therapy in cirrhotic patients seems to not be cost-effective. Furthermore, health care authorities would benefit from treating patients before they develop cirrhosis, as shown by lower ICERs. In this way, as all available treatment strategies for $\mathrm{CHB}$ were evaluated, the model can be employed to make projections of health care spending within the National Health Service.

Based on all these findings, it appears that the "economic" profile of tenofovir is in line with its optimal clinical profile, as outlined in the EASL's guidelines, where, together with pegylated interferon and entecavir, tenofovir is recommended as first-line treatment for both $\mathrm{HBeAg}$-positive and $\mathrm{HBeAg}$ negative subjects with CHB. ${ }^{1}$

The study has a few limitations, the most important of which concerns the quality of data entered into the model. Parameters such as efficacy, for example, are based on studies with a limited timeframe and hence may be inadequate for modeling the treatment of a chronic disease for a longer time. Another important limitation is with regard to the assumptions on which the analysis is based, which may be necessary to simplify the model or in cases of incomplete data. Specifically, this was with regard to the transition probabilities, which were lacking in some cases and thus assumed to remain constant over time, and the utilities, which were derived from different literature sources and considered to be acceptable for an Italian population. 

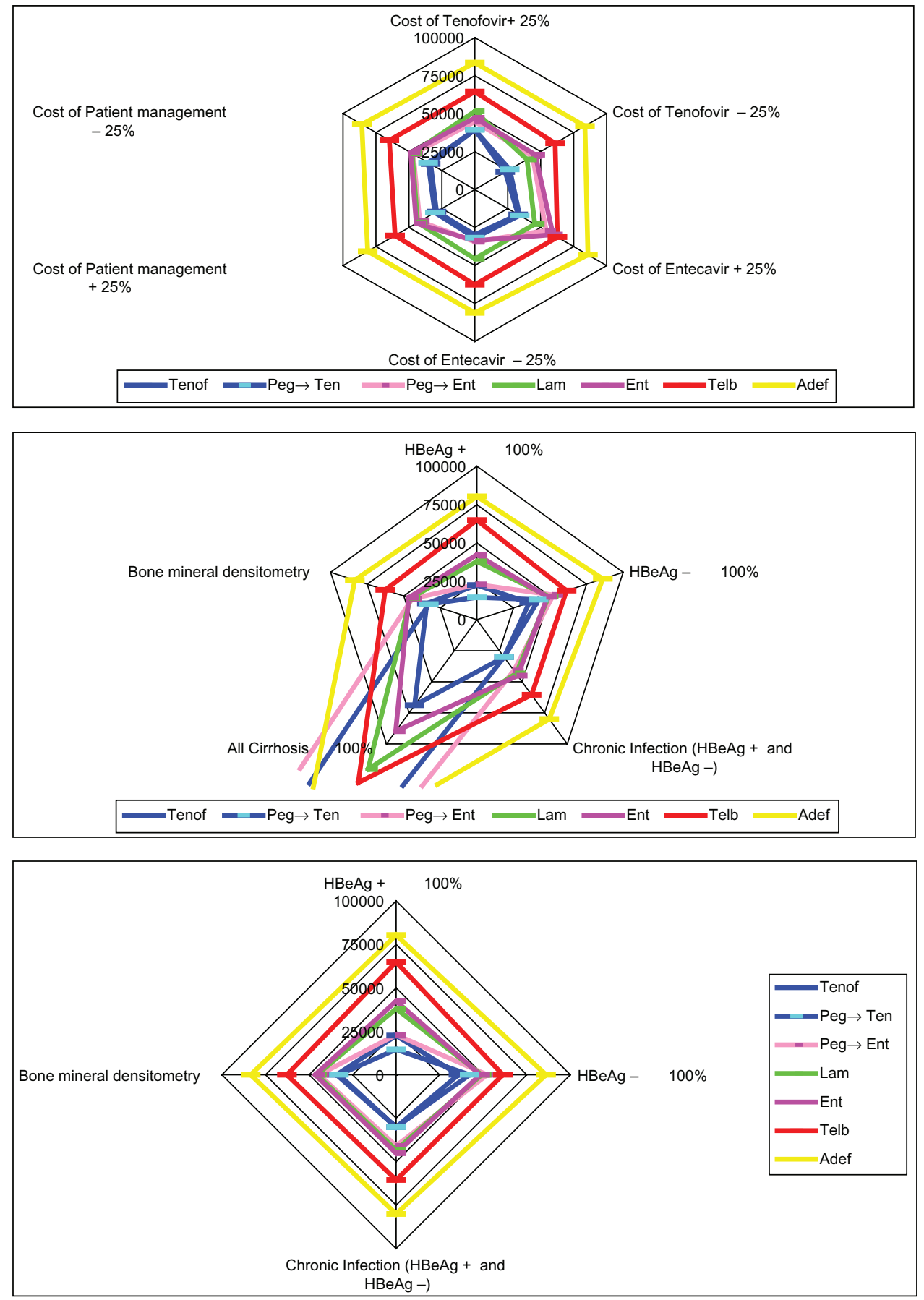

Figure 4 Results of one-way sensitivity analyses.

Despite these drawbacks, which are typical of most model-based economic evaluations, our study contributes to confirming the cost-effectiveness of some drugs, and in particular of tenofovir, also in the Italian context.

To conclude, it is worth noting that the developed model is a dynamic instrument that can be adapted to various health care settings, in that it can be run using different input data (ie, efficacy, cost, and epidemiological). By allowing simulations of different scenarios, it represents an invaluable tool for policy makers and health care professionals to make short- and long-term cost projections and thus evaluate their impact on the available budgets.

\section{Acknowledgements}

We thank Sara A Ratti for preparing the first draft of this paper. 


\section{Declaration}

The study was financially supported by Gilead Sciences Srl, Milan, Italy.

\section{References}

1. European Association for the Study of the Liver. EASL clinical practice guidelines: management of chronic hepatitis B. J Hepatol. 2009;50(2): $227-242$.

2. Dienstag JL. Hepatitis B virus infection. N Engl J Med. 2008;359(14): 1486-1500.

3. Carey I, Harrison PM. Monotherapy versus combination therapy for the treatment of chronic hepatitis B. Expert Opin Investig Drugs. 2009; 18(11):1655-1666.

4. Chang TT, Gish RG, de Man R, et al; BEHoLD AI463022 Study Group. A comparison of entecavir and lamivudine for $\mathrm{HBeAg}$-positive chronic hepatitis B. N Engl J Med. 2006;354(10):1001-1010.

5. Marcellin P, Heathcote EJ, Buti M, et al. Tenofovir disoproxil fumarate versus adefovir dipivoxil for chronic hepatitis B. N Engl J Med. 2008; 359(23):2442-2455.

6. Woo G, Tomlinson G, Nishikawa Y, et al. Tenofovir and entecavir are the most effective antiviral agents for chronic hepatitis B: a systematic review and Bayesian meta-analyses. Gastroenterology. 2010 [Epub ahead of print].

7. Giannini EG, Torre F, Basso M, et al; Ligurian Hepatitis B Virus Study Group. A significant proportion of patients with chronic hepatitis B who are candidates for antiviral treatment are untreated: a region-wide survey in Italy. J Clin Gastroenterol. 2009;43(10):1001-1007.

8. Gaeta GB, Stornaiuolo G, Precone DF, et al. Epidemiological and clinical burden of chronic hepatitis $\mathrm{B}$ virus/hepatitis $\mathrm{C}$ virus infection. A multicenter Italian study. J Hepatol. 2003;39(6):1036-1041.

9. Idris BI, Brosa M, Richardus JH, et al. Estimating the future health burden of chronic hepatitis B and the impact of therapy in Spain. Eur $J$ Gastroenterol Hepatol. 2008;20(4):320-326.

10. Heathcote JE, Gane EJ, de Man A, et al. Two year tenofovir disoproxil fumarate (TDF) treatment and adenofovir dipivoxil (ADV) switch data in HbeAg-positive patients with chronic hepatitis B (Study 103), preliminary analysis [Abstract]. Hepatology. 2008;48 Suppl 4:309A.

11. Heathcote JE, Gane EJ, de Man A, et al. Three years of tenofovir disoproxil (TDF) treatment in HbeAg-positive patients ( $\mathrm{HBeAg}+)$ with chronic hepatitis B (Study 103), preliminary analysis [Abstract]. Hepatology. 2009;50 Suppl 4:533A.

12. Chang TT, Gish RG, de Man R, et al. A comparison of entecavir and lamivudine for HBeAg-positive chronic hepatitis B. $N$ Engl J Med. 2006;354(10):1001-1010.

13. Lai CL, Yuen MF. Chronic hepatitis B: new goals, new treatment. N Engl J Med. 2008;359(23):2488-2491.

14. Marcellin P, Chang TT, Lim SG, et al. Adefovir dipivoxil for the treatment of hepatitis B e antigen-positive chronic hepatitis B. N Engl J Med. 2003;348(9):808-816.

15. Lai CL, Gane E, Liaw YF, et al. Telbivudine versus lamivudine in patients with chronic hepatitis B. N Engl J Med. 2007;357(25):2576-2588.

16. Lai CL, Gane E, Hsu CW, et al. Two-year results from the globe trial in patients with hepatitis B: greater clinical and antiviral efficacy for telbivudine (LDT) vs lamivudine [Abstract]. Hepatology. 2006;44 Suppl 1:222A.

17. Marcellin P, Buti M, Krastev Z, et al. Two year tenofovir disoproxil fumarate (TDF) treatment and adenofovir dipivoxil (ADV) switch data in HbeAg-negative patients with chronic hepatitis B (Study 102), preliminary analysis [Abstract]. Hepatology. 2008;48 Suppl 4:370A.

18. Marcellin P, Buti M, Krastev Z, et al. Three years of tenofovir disoproxil (TDF) treatment in HbeAg-positive patients $(\mathrm{HBeAg}+)$ with chronic hepatitis B (Study 103), preliminary analysis [Abstract]. Hepatology. 2009;50 Suppl 4:532A.
19. Di Marco V, Marzano A, Lampertico P, et al. Italian Association for the Study of the Liver (AISF) Lamivudine Study Group, Italy. Clinical outcome of $\mathrm{HBeAg}$-negative chronic hepatitis $\mathrm{B}$ in relation to virological response to lamivudine. Hepatology. 2004;40(4):883-891.

20. Hadziyannis SJ, Tassopoulos NC, Heathcote EJ, et al. Adefovir Dipivoxil 438 Study Group. Long-term therapy with adefovir dipivoxil for HBeAg-negative chronic hepatitis B for up to 5 years. Gastroenterology. 2006;131(6):1743-1751.

21. Senturk H, Lurie Y, Gadano A, et al. ETV re-treatment of nucleosidenaive $\mathrm{HBeAg}(-)$ [Abstract]. J Hepatol. 2007;46 Suppl 1:S197.

22. Shouval D, Lai CL, Chang TT, et al. Three years of entecavir (ETV) re-treatment of $\mathrm{HBe} A g(-)$ ETV patients who previously discontinued ETV treatment: results from study ETV-901. Hepatology. 2008;48 Suppl 4:722A.

23. Lai CL, Shouval D, Lok AS, et al; BEHoLD AI463027 Study Group. Entecavir versus lamivudine for patients with $\mathrm{HBeAg}$-negative chronic hepatitis B. N Engl J Med. 2006;354(10):1011-1020. Erratum in: N Engl J Med. 2006;354(17):1863.

24. Shouval D, Akarca US, Hatzis G, et al. Continued virologic and biochemical improvement through 96 weeks of entecavir treatment in $\mathrm{HBeAg}(-)$ chronic hepatitis B patients (study ETV-027). J Hepatol. 2006;44 Suppl 2:S21-S22.

25. Wang $\mathrm{Y}$, Thongsawat $\mathrm{S}$, Gane EJ, et al. Efficacy and safety outcomes after 4 years of telbivudine treatment in patients with chronic hepatitis B (CHB). Hepatology. 2009;50 Suppl 4:533A.

26. Snow-Lampart A, Chappell BJ, Curtis M, et al. HBeAg+ and HBeAghepatitis B patients treated with tenofovir df showed no relationship between virologic breakthrough and emergence of genotypic changes in HBV polymerase. Hepatology. 2009;50 Suppl 4:523A.

27. Lok AS, Lai CL, Leung N, et al. Long-term safety of lamivudine treatment in patients with chronic hepatitis B. Gastroenterology. 2003; 125(6): 1714-1722.

28. Marcellin P, Chang TT, Lim SG, et al. Long-term efficacy and safety of adefovir dipivoxil for the treatment of hepatitis B e antigen-positive chronic hepatitis B. Hepatology. 2008;48(3):750-758.

29. Tenney DJ, Rose RE, Baldick CJ, et al. Long-term monitoring shows hepatitis B virus resistance to entecavir in nucleoside-naïve patients is rare through 5 years of therapy. Hepatology. 2009;49(5):1503-1514.

30. Liaw YF, Gane E, Leung N, et al. GLOBE Study Group. 2-year GLOBE trial results: telbivudine is superior to lamivudine in patients with chronic hepatitis B. Gastroenterology. 2009;136(2):486-495.

31. Fontana RJ. Hepatitis B: a "GLOBAL" health challenge. Gastroenterology. 2009;136(2):389-392.

32. Buster EH, Flink HJ, Cakaloglu Y, et al. Sustained HBeAg and HBsAg loss after long-term follow-up of $\mathrm{HBeAg-positive} \mathrm{patients} \mathrm{treated} \mathrm{with}$ peginterferon alpha-2b. Gastroenterology. 2008;135(2):459-467.

33. Janssen HL, van Zonneveld M, Senturk H, et al. HBV 99-01 Study Group; Rotterdam Foundation for Liver Research. Pegylated interferon alfa-2b alone or in combination with lamivudine for HBeAg-positive chronic hepatitis B: a randomised trial. Lancet. 2005;365(9454):123-129.

34. Marcellin P, Lau GK, Bonino F, et al. Peginterferon Alfa-2a HBeAgNegative Chronic Hepatitis B Study Group. Peginterferon alfa-2a alone, lamivudine alone, and the two in combination in patients with HBeAg-negative chronic hepatitis B. N Engl J Med. 2004;351(12): 1206-1217.

35. Marcellin P, Bonino F, Lau GK, et al. Peginterferon alfa-2a in HBeAgnegative Chronic Hepatitis B Study Group. Sustained response of hepatitis $\mathrm{B}$ e antigen-negative patients 3 years after treatment with peginterferon alpha-2a. Gastroenterology. 2009;136(7):2169-2179:e1-e4.

36. Lau GK. Current treatments for patients with $\mathrm{HBeAg}$-positive chronic hepatitis B virus infection: a comparison focusing on $\mathrm{HBeAg}$ seroconversion. Liver Int. 2010;30(4):512-520.

37. Marcellin P, Chang TT, Lim S, et al. Long term efficacy and safety of adefovir dipivoxil (ADV) $10 \mathrm{mg}$ in $\mathrm{HBeAg}+$ chronic hepatitis $\mathrm{B}$ (CHB) patients increasing serologic, virologic and biochemical response over time. Hepatology. 2004;40(1) Suppl 4:655A. 
38. Leung N, Peng CY, Sollano J, et al. Entecavir (ETV) results in higher HBV DNA reduction versus adefovir (ADV) in antiviralnaive $\mathrm{HBeAg}+$ adults with high HBVDNA: Week 96 results (E.A.R.L.Y. study). J Hepatol. 2008;48:S373-S374.

39. Yao G, Chen CW, Lu WL, et al. Virologic, serologic, and biochemical outcomes through 2 years of treatment with entecavir and lamivudine in nucleoside-naive Chinese patients with chronic hepatitis B: a randomized, multicenter study. Hepatol Int. 2008;2:486-493.

40. Han S, Chang T-T, Chao YC, et al. Four-year entecavir treatment in nucleosidenaïve $\mathrm{HBe} \mathrm{Ag}(+)$ patients: results from studies ETV-022 And -901. Hepatology. 2007;46(4) Suppl 1:654A.

41. Hou J, Yin YK, Xu D, et al. Telbivudine versus lamivudine in Chinese patients with chronic hepatitis B: results at 1 year of a randomized, double-blind trial. Hepatology. 2008;47:447-454.

42. Piratvisuth T, Lau G, Chao YC, et al. Sustained response to peginterferon alfa-2a $(40 \mathrm{kD})$ with or without lamivudine in Asian patients with $\mathrm{HBeAg}$-positive and $\mathrm{HBeAg}$-negative chronic hepatitis B. Hepatol Int. 2008;2(1):102-110.

43. Drummond MF, Schulpher MJ, Torrance GW, et al. Methods for the Economic Evaluation of Health Care Programmes. 3rd ed. Oxford: Oxford University Press; 2005.

44. Enriquez AD, Campbell MS, Reddy KR. Cost-effectiveness of suppressing hepatitis B virus DNA in immune tolerant patients to prevent hepatocellular carcinoma and cirrhosis. Aliment Pharmacol Ther. 2007;26(3):383-391.

45. Sullivan SD, Craxi A, Alberti A, et al. Rapporto costo efficacia della terapia peginterferone alfa-2a+ribavirina in confronto a interferone alfa-2b+ribavirina in pazienti affetti da epatite cronica di tipo $\mathrm{C}$ precedentemente non trattati. PharmacoEconomics. 2004;6:105-114.

46. Kanwal F, Gralnek IM, Martin P, et al. Treatment alternatives for chronic hepatitis B virus infection: a cost-effectiveness analysis. Ann Intern Med. 2005;142(10):821-831.

47. Chapman RH, Stone PW, Sandberg EA, et al. A comprehensive league table of cost-utility ratios and a sub-table of "panel-worthy" studies. Med Decis Making. 2000;20(4):451-467.

48. Health Ministry. National Tariff Nomenclature. Nomenclatore delle Prestazioni di assistenza specialistica ambulatoriale. Ministero della Salute; 2010.
49. Conferenza delle Regioni e delle Province autonome 1O/014/CR10a/C7. DRG 206, Tariffa Unica Convenzionale (TUC) per le prestazioni di assistenza ospedaliera, regole e tariffe valide per l'anno 2009secondo CMS-DRG Versione 24. DRG 206; DRG 202; DRG 199; DRG 480; Roma 2010

50. Tumiatti C, Bezzon C, Guasti F, Franchin M. Il costo del trapianto d'organo: risultati di uno studio condotto presso l'Azienda Ospedaliera di Padova. Azienda Ospedaliera di Padova. 1999:39. valori attualizzati al 2009.

51. Gazzetta Ufficiale n 216 of 14/09/1996: DM 22/07/1996; 89.7: visita specialistica, prima visita. Prestazioni di assistenza specialistica ambulatoriale erogabili nell'ambito del Servizio sanitario nazionale e relative tariffe.

52. Gazzetta Ufficiale n 216 of 14/09/1996: DM 22/07/1996;90.16.3: creatinina, 90.24 .3 fosfato organico. Prestazioni di assistenza specialistica ambulatoriale erogabili nell'ambito del Servizio sanitario nazionale e relative tariffe.

53. The National Institute for Health and Clinical Excellence. Social value judgements: principles for the development of NICE guidance. Second ed. 2008. http://www.nice.org.uk/media/C18/30/ SVJ2PUBLICATION2008.pdf. Accessed July 14, 2010.

54. Buti M, Brosa M, Casado MA, et al. Modeling the cost-effectiveness of different oral antiviral therapies in patients with chronic hepatitis B. J Hepatol. 2009;51(4):640-646.

55. Dakin H, Bentley A, Dusheiko G. Cost-utility analysis of tenofovir disoproxil fumarate in the treatment of chronic hepatitis B. Value Health. September 3, 2010. [Epub ahead of print].

56. Associazione Italiana di Economia Sanitaria (AIES). Proposta di linee guida per la valutazione economica degli interventi sanitari. PharmacoEconomics - Italian Research Articles. 2009;11: 83-93.

57. Lucioni C, Ravasio R. Come valutare i risultati di uno studio farmacoeconomico?. PharmacoEconomics - Italian Research Articles. 2004;(3):121-130.

58. Messori A, Santarlasci B, Trippoli S, Vaiani M. Controvalore economico del farmaco e beneficio clinico: Stato dell'arte della metodologia e applicazione di un algoritmo farmacoeconomico. PharmacoEconomics - Italian Research Articles. 2003;5:53-67.
ClinicoEconomics and Outcomes Research

\section{Publish your work in this journal}

ClinicoEconomics \& Outcomes Research is an international, peerreviewed open-access journal focusing on Health Technology Assessment, Pharmacoeconomics and Outcomes Research in the areas of diagnosis, medical devices, and clinical, surgical and pharmacological intervention. The economic impact of health policy and health systems

\section{Dovepress}

organization also constitute important areas of coverage. The manuscript management system is completely online and includes a very quick and fair peer-review system, which is all easy to use. Visit http://www.dovepress.com/testimonials.php to read real quotes from published authors. 